\title{
Entrepreneurship Education in Malaysia's Public Institutions of Higher Learning-A Review of the Current Practices
}

\author{
Mohd Nor Hakimin Bin Yusoff ${ }^{1}$, Fakhrul Anwar Zainol ${ }^{2}$ \& Mohamed Dahlan Bin Ibrahim $^{1}$ \\ ${ }^{1}$ University Malaysia Kelantan, Pengkalan Chepa, Kota Bharu, Kelantan, Malaysia \\ ${ }^{2}$ University Sultan Zainal Abidin, Kuala Terengganu, Terengganu, Malaysia \\ Correspondence: Fakhrul Anwar Zainol, University Sultan Zainal Abidin, Kuala Terengganu, Terengganu, \\ Malaysia. E-mail: fakhrulanwar@unisza.edu.my
}

$\begin{aligned} & \text { Received: September 17, } 2014 \quad \text { Accepted: October 20, } 2014 \quad \text { Online Published: December } 30,2014 \\ & \text { doi:10.5539/ies.v8n1p17 }\end{aligned} \quad$ URL: http://dx.doi.org/10.5539/ies.v8n1p17

\begin{abstract}
The need for a practical and applicable model for entrepreneurial learning is becoming critical. In this study, we aimed to collect data related to entrepreneurship education practices by all institutes of higher learning (IHLs) in Malaysia as well as challenges faced, facilities, and supports offered by the universities. Given the important role of IHLs to nurture and to create future entrepreneurs, the government via public IHLs aspires to produce "job creators" rather than "job seekers." The findings of the study are significant as they provide practical insight into the entrepreneurship education practiced by the local public universities. In addition, the study also contributes to the present literature on the entrepreneurship education in Malaysia, particularly in presenting the practical issues and challenges faced by the universities in conducting entrepreneurship education programs.
\end{abstract}

Keywords: entrepreneurship education, enterprise education, public university

\section{Introduction}

The need for a practical and applicable model for entrepreneurial learning is becoming critical. In this study, we aimed to collect data related to entrepreneurship education practices by all institutes of higher learning (IHLs) in Malaysia as well as challenges faced, facilities, and supports offered by the universities. Altogether Malaysia has 20 -government funded universities across the country. The government is divided into 14 regions, which are called states. Each of these 14 states has at least one public university; however, few states have more than one public university. Permodalan Nasional Berhad (National Capital Limited) funded this study.

Generally, people believe that entrepreneurial skills can be learned by inculcating entrepreneurship knowledge to students. Supposedly, students with entrepreneurship knowledge are more inclined towards venturing into business than are those who have not been exposed to this knowledge. For that reason, entrepreneurship education has turned out to be the central focus of the education ministry, and educators are encouraged to promote an entrepreneurial learning pedagogy that combines classroom theoretical lectures and practical learning outside the classroom to obtain a good impact and an enriched learning experience. Furthermore, students are exposed to the self-directed learning together with problem-based learning, which is proven to have a significant impact on students' entrepreneurial intentions.

Nevertheless, some educators still oppose the idea of students venturing into the business while they are still pursuing their studies (Fayolle \& Gailly, 2008). They have reasoned that business activities may interfere with students' learning time and affect students' focus on their studies. They have also argued that spending more time on business activities may contribute to students' psychological and physiological problems due to fatigue. Despite these educators' criticisms, most universities believe in the benefits of entrepreneurship education and have aggressively promoted the subjects.

Scholars have different views in defining entrepreneurship education. For universities in Finland, this education is called enterprise ownership and intrapreneurship, and it is more inclined to the traditional way of defining entrepreneurship. In Great Britain and Ireland, entrepreneurship education is called enterprise education. The curriculum content is more focused on individual capacity building, i.e. entrepreneurial attributes. Therefore, the establishment of the business entity is not the ultimate outcome of the curriculum (Nurmi \& Paasio, 2007). The diversity of concepts and opinions provides the opportunity for researchers to conduct empirical studies to 
narrow the gap in the existing relevant literature. The findings from this particular study will also provide a basis to develop a new entrepreneurship education model that considers the deficiencies in the current model. The proposed model would become a blueprint and act as guidelines for all IHLs to implement effective entrepreneurship education programs and activities.

Our main objective for this study was to collect data about the entrepreneurship programs conducted and support provided by Malaysia's public IHLs. The study is also aimed to identify challenges faced by the universities while promoting their entrepreneurship education programs. Given the important role of IHLs to nurture and to create future entrepreneurs, the government via public IHLs aspires to produce "job creators" rather than "job seekers." The findings of the study are significant as they provide practical insight into the entrepreneurship education practiced by the local public universities. In addition, the study also contributes to the present literature on the entrepreneurship education in Malaysia, particularly in presenting the practical issues and challenges faced by the universities in conducting entrepreneurship education programs.

\section{Methodology}

For this study, we used a qualitative approach where the data were gathered via structured, personal interviews and open-ended questions. We selected this stratified sampling approach and the respondents from each of the 20 public universities. The respondents were personally responsible in the administration, supervision, and coordination of entrepreneurship programs at their respective universities. The data gathered were analysed using a descriptive comparison technique.

The questionnaires were divided into six parts. Part A was about the university's entrepreneurship development model. The respondents were required to answer on the availability of such model and whether it is documented as a policy paper. Most of the questions in Part A consisted of dichotomous questions that required respondents to give a yes or no answer. Part B consisted of four questions. The first question was about whether each respondent's school had a compulsory entrepreneurship course. Secondly, respondents reported the credit hours allocated for the course (if any). The third question required respondents to complete the information on the programs undertaken by the university such as the "Students Entrepreneurship Training Series" or "Modules and Students Basic Entrepreneurship Course." We also requested that the respondents furnish information on the entrepreneurship co-curriculum activities at their universities, including exhibitions, ad-hoc sales stalls, community services, tea-talk, and promotion, among others. The fourth question addressed the issue of the lecturers' qualifications. We asked respondents to identify an area of expertise for a skilled lecturer. Part $\mathrm{C}$ included questions about the entrepreneurship education's targeted group and the university's policies regarding student business activities.

In Part D, the questions were about the entrepreneurship support programs available in the respondents' respective IHLs. We asked respondents to identify the availability of support, the type of support, and the programs held to promote entrepreneurship education programs. The questions in Part E were about the effectiveness of the entrepreneurship curriculum practiced by the IHLs. Respondents responded to questions about the effectiveness of the curriculum and the number of graduate entrepreneurs that university had produced. In addition, we asked respondents to list the problems and challenges faced by students, and then to propose solutions to overcome the problems. Finally, Part F included questions to gather the information pertaining to the respondents' demographic profiles, such as age, education levels, areas of expertise, locations, yeasr of services, and employers' addresses.

\section{Literature Review}

Entrepreneurship plays an important role in promoting economic activities in the country by creating job opportunities, and it contributes significantly to the country's gross domestic product (National SME Development Council, 2007). Considering the significant contribution to the economic development and prosperity of the country, the government has intensified its effort in promoting entrepreneurship activities among its citizens. Besides acting as a catalyst to wealth creation, entrepreneurial activities also bring benefits in terms of less dependence on the government in providing job opportunities. Thus, nurturing the mental attitude towards entrepreneurial activities among students can be done through the entrepreneurship education process (Gorman, Hanlon, \& King, 1997).

\subsection{Nurturing Entrepreneurship Culture via Formal Education}

Previous studies have shown that entrepreneurship is a discipline similar to any other discipline and therefore it can be learned. A person is neither born nor fated to be an entrepreneur. Researchers have expressed the belief that entrepreneurs can be created by way of effective education, training, and the nurturing process. Drucker (1994) posited that: 
Most of what you hear about entrepreneurship is all wrong. It's not magic, it's not mysterious; and it has nothing to do with genes. It's a discipline and, like any other discipline, it can be learned.

Based on the above argument, the entrepreneurship programs offered by local public universities either in the form of a compulsory core subject or embedded in the curriculum is aimed to produce as many graduate entrepreneurs as possible. Nevertheless, the impact has not been satisfactory if the program has failed to attract graduates to venture into entrepreneurship activities immediately after graduation. This phenomenon attracts sceptics who criticize public universities for failing to produce graduate entrepreneurs, while other institutions, such as technical and other vocational training centres, have succeeded. A study conducted by Cheng, Chan, and Mahmood (2009), revealed that the effectiveness of entrepreneurship education in Malaysia is correlated with the content of the curriculum. The study revealed that the content of the present curriculum has not met the requirements and that there is a clear mismatch with the students' expectations.

\subsection{The Essentials of Entrepreneurship Education}

The main objective of entrepreneurship education in public IHLs is to produce entrepreneurial graduates as well as graduate entrepreneurs. Entrepreneurship education has been promoted based on the belief that entrepreneurship can be nurtured and learnt. In addition, continuous exposure to entrepreneurship activities can enhance students' inclination to venture into these activities. In addition to a students' acquiring the entrepreneurship knowledge and experience, their family backgrounds, personal experiences, and external environment were also found to influence their intentions towards involvement in entrepreneurship activities. People with a family background in business tend to have higher inclinations towards entrepreneurial activities compared to those who do not (Dahlan, Hakimin, \& Azwin, 2010). Early and continuous exposure to entrepreneurship activities have inculcated the tacit knowledge that was found to positively influence a person's intention and behaviour to venture into business in particular. On the other hand, students who have been exposed to entrepreneurship education were found to positively correlate to an inclination towards venturing into business. They possessed entrepreneurial characteristics and act entrepreneurially compared to other student without similar exposure (Cheng et al., 2009). Thus, entrepreneurship education becomes vital to nurturing and encouraging students to choose entrepreneurship as a career option. Therefore, the number of graduate entrepreneurs will likely increase if more students are exposed to entrepreneurship education programs and activities in the university. Curriculum, however, should be designed to maximize students' learning experience via the entrepreneurship education and enterprise education models. Conversely, students who have previous working experience could perform entrepreneurially as they already possess many entrepreneurial characteristics. Under the current employment scenario, prospective employers prefer students who can act entrepreneurially as they are able to deal with the dynamics of the business environment ( $\operatorname{Tan} \& \mathrm{Ng}, 2006$ ).

\subsection{The Delivery Method}

Most of the existing entrepreneurship education curriculum emphasises the theoretical knowledge and gives less attention to the practical application of the subject. The programs accentuate the established knowledge; however, they are frail on skill development and tacit experiences, which are critical features for nascent entrepreneurs (Dhliwayo, 2008). Presently, in the conventional way of teaching entrepreneurship, students are exposed to the philosophy and theory with minimum exposure to the practical aspects. The applications to imagination, creativity, and innovation have only been theoretically explained, and as a result, students have been unable to emulate and grasp the experience of being an entrepreneur. This particular shortcoming needs to be revamped as its failure entails serious implications on government expenditures because it involves a huge amount of money and wastes a lot of time. In addition, an urgent review of the conventional approach is needed as it does not emphasise the lecturer's abilities within the entrepreneurship subject. Such a review is more critical for cases when the lecturer has insufficient experience and knowledge about entrepreneurship. To overcome such a problem, the entrepreneurship educators' competency should be intensified via continuous learning and competency-building through business sabbaticals in order for them to gain more experience that would enhance their teaching effectiveness. Experiential learning is a pedagogical approach that enhances the process of knowledge acquisition via an experience-transformation process. This approach postulates that effective learning can only take place when experience is acquired (Dhliwayo, 2008).

Due to the weaknesses that have prevailed in the current teaching techniques, many researchers have introduced a number of teaching approaches in entrepreneurship education. New learning models have been promoted to enhance the effectiveness of the process of nurturing and motivating students towards entrepreneurial activities. A South African University has come out with the "Entrepreneurial Performance Education Model" (EPEM) and the "Entrepreneurial Education Model" (EEM) (Van Vuuren \& Nieman, 1999). EPEM emphasizes motivation, 
entrepreneurial skills, and business skills that influence entrepreneurial performance. EEM takes into account the fact that the facilitator and the teaching approach are essential elements in the education program (Pretorius, Nieman, \& van Vuuren, 2005).

Cheng et al.'s (2009) study showed that university students have indicated no significant relationship between entrepreneurship knowledge and intent to venture into business. The study revealed that the current entrepreneurship education has failed to enhance students' inclination to choose entrepreneurship as a career option. Respondents gave such feedback as the following: inexperienced lecturers, ineffective methodologies that are examination oriented and too theoretical, and insufficient practical exposure. Cheng et al. (2009) also found that $84 \%$ of the programs were conducted via lectures, $11.5 \%$ by way of case study, and $6.3 \%$ lectures were delivered by guest speakers. The study showed that most of the entrepreneurship learning process was done through classroom teaching, which is theoretical in nature. The findings suggested that entrepreneurship philosophy was not well delivered because the majority of the respondents perceived entrepreneurs as being born and therefore an average person could not be trained. Such a myth may drive students to assume that nobody can turn him or herself into a successful entrepreneur even when acquiring entrepreneurship education (Jones \& English, 2004), or that no one can become an entrepreneur unless he or she were born to be one.

\section{Findings}

We have divided the findings of the current study into three subsections: (1) findings about the support according to each university's authority and type of support, (2) related activities, and (3) the respondents' challenges and suggestions to resolve such problems.

Malaysia has 20 public universities located across the country, and each state has at least one public university. The study found that only 1 out of the 20 universities has not introduced any entrepreneurship program-Universiti Pertahanan Malaysia (Defence University of Malaysia). The reason for this lack is that this university's educational objective is to produce high ranking army personnel, thus they have nothing to do with entrepreneurship. The survey results showed that 19 public universities have indicated that they carry out entrepreneurship programs as a core subject. Details of the finding are in the following subsections.

\subsection{Support}

Table 1 below summarizes the various types of support that may enhance the success of entrepreneurship programs executed in Malaysia's public universities.

\subsubsection{The Management Support}

$85 \%$ of the respondents agreed that the entrepreneurship programs received strong support from their universities' top management. The balance of $15 \%$ claimed that their entrepreneurship programs are not well supported by the top management.

\subsubsection{Infrastructure Support}

$80 \%$ of the respondents agreed that the infrastructure for entrepreneurship activities were available in the universities while $25 \%$ of the respondents claimed that their universities had insufficient infrastructure available to support the entrepreneurship programs.

\subsubsection{Promotion, Funding, and Advisory}

$25 \%$ of the respondents claimed they did not conduct a comprehensive promotion program to promote the entrepreneurial activities and programs among students. Six universities were found to have no provision for funding students' business activities while seven universities did not have external experts to advise on the conducted programs. 
Table 1. List of support offered

\begin{tabular}{|c|c|c|c|c|c|}
\hline \multirow{2}{*}{ Institute of Higher Learning } & \multicolumn{5}{|c|}{ Support } \\
\hline & Management & Infrastructure & Promotion & Funding & Advisory \\
\hline Univ Malaysia Kelantan & $\sqrt{ }$ & $\sqrt{ }$ & $\mathrm{X}$ & $\mathrm{X}$ & $\sqrt{ }$ \\
\hline Univ Teknoloji Malaysia & $\sqrt{ }$ & $\sqrt{ }$ & $\mathrm{X}$ & $\mathrm{X}$ & $\sqrt{ }$ \\
\hline Univ Teknologi Hussin Onn & $\sqrt{ }$ & $\sqrt{ }$ & $\sqrt{ }$ & $\mathrm{X}$ & $\mathrm{X}$ \\
\hline Univ Sains Malaysia & $\sqrt{ }$ & $\sqrt{ }$ & $\sqrt{ }$ & $\sqrt{ }$ & $\sqrt{ }$ \\
\hline Univ Malaya & $\sqrt{ }$ & $\sqrt{ }$ & $\sqrt{ }$ & $\sqrt{ }$ & $\sqrt{ }$ \\
\hline Univ Kebangsaan Malaysia & $\sqrt{ }$ & $\sqrt{ }$ & $\sqrt{ }$ & $\sqrt{ }$ & $\sqrt{ }$ \\
\hline Univ Putra Malaysia & $\sqrt{ }$ & $\sqrt{ }$ & $\sqrt{ }$ & $\sqrt{ }$ & $\sqrt{ }$ \\
\hline Univ Teknologi MARA & $\sqrt{ }$ & $\sqrt{ }$ & $\sqrt{ }$ & $\sqrt{ }$ & $\sqrt{ }$ \\
\hline Univ Malaysia Perlis & $\sqrt{ }$ & $\sqrt{ }$ & $\sqrt{ }$ & $\sqrt{ }$ & $\sqrt{ }$ \\
\hline Univ Utara Malaysia & $\sqrt{ }$ & $\sqrt{ }$ & $\sqrt{ }$ & $\sqrt{ }$ & $\sqrt{ }$ \\
\hline Univ Malaysia Pahang & $\mathrm{X}$ & $\mathrm{X}$ & $\sqrt{ }$ & $\sqrt{ }$ & $\mathrm{X}$ \\
\hline Univ Sultan Zainal Abidin & $\sqrt{ }$ & $\mathrm{X}$ & $\mathrm{X}$ & $\sqrt{ }$ & $\mathrm{X}$ \\
\hline Univ Malaysia Terengganu & $\sqrt{ }$ & $\mathrm{X}$ & $\sqrt{ }$ & $\sqrt{ }$ & $\mathrm{X}$ \\
\hline Univ Perguruan Sultan Idris & $\sqrt{ }$ & $\sqrt{ }$ & $\sqrt{ }$ & $\mathrm{X}$ & $\sqrt{ }$ \\
\hline Univ Pertahanan Malaysia & $\mathrm{X}$ & $\mathrm{X}$ & $\mathrm{X}$ & $\mathrm{X}$ & $\mathrm{X}$ \\
\hline Univ Sains Islam Malaysia & $\sqrt{ }$ & $\sqrt{ }$ & $\sqrt{ }$ & $\sqrt{ }$ & $\sqrt{ }$ \\
\hline Univ Teknikal Melaka & $\mathrm{X}$ & $\mathrm{X}$ & $\mathrm{X}$ & $\mathrm{X}$ & $\mathrm{X}$ \\
\hline Univ Malaysia Sabah & $\sqrt{ }$ & $\sqrt{ }$ & $\sqrt{ }$ & $\sqrt{ }$ & $\sqrt{ }$ \\
\hline Univ Malaysia Sarawak & $\sqrt{ }$ & $\sqrt{ }$ & $\sqrt{ }$ & $\sqrt{ }$ & $\sqrt{ }$ \\
\hline Univ Islam Antarabangsa & $\sqrt{ }$ & $\sqrt{ }$ & $\sqrt{ }$ & $\sqrt{ }$ & $\sqrt{ }$ \\
\hline
\end{tabular}

\subsection{Activities}

\subsubsection{Entrepreneurship Development Model}

Most of the universities have adopted an education model for entrepreneurship programs as outlined by the Ministry of Education (MOE). However, three universities have applied their own models. The IHLs are Universiti Malaysia Kelantan, Univversit Utara Malaysia, and Universiti Teknologi MARA.

\subsubsection{Entrepreneurship Courses}

All respondents agreed that, in order to adhere to policy stipulated by MOE, their university have made an entrepreneurship course compulsory for all students. However, each IHL has slight differences in terms of the number of credit hours given to students, including between two and three credits.

4.2.3 Students Entrepreneurship Training, Entrepreneurship Students Basic Course, and Graduate Entrepreneur Development Programs

All of the programs are implemented at each of the public IHLs except the National Defence University of Malaysia. UMK, however, has used different terminology and approaches in implementing these programs.

\subsubsection{Entrepreneurial Activities}

The entrepreneurial activities that include seminars, workshops, community service, entrepreneurship clubs (or a combination of these) have been implemented in all IHLs as extra-curricular activities. Additionally, some IHLs have been implementing their own programmes, as shown in the Table 2 . 
Table 2. Internally developed programs

\begin{tabular}{lll}
\hline No & IHL & Program/Activity \\
\hline 1 & UMK & PELS, CLS, SIEP, SEED, SEC. \\
2 & USM & SIFE, SEDIA, Technopreneurs \\
3 & UiTM & SIFE, Technology entrepreneur \\
4 & UniMAP & Business Game \\
5 & UTHM & Ko Siswa \\
6 & UTM/UUM & Student's Mall \\
7 & UMS & Business and Economy School Week, Workshop, Entrepreneurship Program
\end{tabular}

Note: PELS-Prime Entrepeneur Lecture Series, CLS-Chairman Lecture Series, SIEP-Students in Enterprise Programs, SEED -Social Enterprise and Economic Development, SEC-Student Enterprise Center, SIFE-Student in Free Enterprise

\subsubsection{Entrepreneurship Educators}

In terms of delivery, respondents reported that half of the IHLs employ a combination of people from academic and professional/industrial backgrounds. However, some lecturers with no entrepreneurship education qualification and background have been appointed as trainers.

\subsubsection{Target Groups}

Participants reported that all IHLs' students are the targeted groups. Almost all IPTAs set target entrepreneurship education to all students, irrespective of their discipline of study. In addition, a number of IHLs have extended the scope of entrepreneurship education to include their alumni, the rural community, and post-graduate students.

\subsubsection{University Policy}

Fourteen public IHLs have set up policy governing the students' entrepreneurial activities, academic achievements, and students' business loans.

Out of 21 IHLs, 19 have received support in various forms for their entrepreneurship activities. The supports include help with management, infrastructure, promotion, financing, and advisory services. Furthermore, eight IHLs claimed that they are practicing scheduled monitoring on the effectiveness of the entrepreneurship education in their respective IHLs.

The findings showed that only five IHLs (UKM, UUM, UiTM, USIM and UMS) have undertaken a study on their entrepreneurship education effectiveness. Almost $50 \%$ of the IHLs have maintained and kept track of the number of their graduates who have successfully ventured into business.

The above findings indicate that entrepreneurship education has been one of the core programs in Malaysian public IHLs. However, they also indicate various approaches in the implementation of the programs. Such variance is due to the degree of emphasis the respective IHLs have given to entrepreneurship education. Therefore, Malaysia IHLs have need for a study to compare and to assess the various models currently being applied in the IHLs so that a more comprehensive entrepreneurship education model can be developed and implemented in all public IHLs.

\subsection{Challenges Faced by IHLs}

According to the feedback, the majority of the IHLs recognize the current challenges faced in executing entrepreneurship education into the present curriculum. The challenges include lacks in soft skills, in financing, and in commitment from all parties. At the top of the list was a lack of soft skills among the students. Students following the entrepreneurship programs lacked communication skills, leadership skills, knowledge of marketing strategies, general business knowledge, and abilities in networking. The second top challenge cited was the difficulty of students to obtain loans to start their business on campus. The third top challenge was lack of commitment among IHLs' staff and students. This feedback came from five IHL participants who found that staff and students were not committed to the entrepreneurship programs. The list of challenges here is a based on the rankings of the most frequently mentioned challenges, as noted in Table 3. 
Table 3. List of challenges

\begin{tabular}{ll}
\hline & Most frequently mentioned \\
\hline 1. Students soft skill \\
2. Financing \\
3. Commitment \\
4. Coordination among support agencies \\
5. Bureaucracy \\
6. Manager support \\
7. Staff and student mentality \\
8. Pedagogy \\
\hline
\end{tabular}

Other challenges include the issue of coordination among support agencies, bureaucracy, and lack of management support, unfavourable mentality among staff and students towards entrepreneurship activities, and ineffectual pedagogy.

Table 4. Challenges and suggestion of solutions

\begin{tabular}{|c|c|c|}
\hline Institute of Higher Learning & Challenges & Recommendations \\
\hline Univ Malaysia Kelantan & $\mathrm{X}$ & $\mathrm{X}$ \\
\hline Univ Teknoloji Malaysia & $\begin{array}{l}\text { Lack of interest among students, capital } \\
\text { funding, experience, skill, financial } \\
\text { management, coordination, space }\end{array}$ & $\begin{array}{l}\text { Space, grant, Mentor-mentee, } \\
\text { Skill development, subsidy }\end{array}$ \\
\hline Univ Teknologi Hussin Onn & $\begin{array}{l}\text { Financing, networking, lack of } \\
\text { knowledge, mentality }\end{array}$ & $\begin{array}{l}\text { Standardised term of financing, } \\
\text { financial knowledge, } \\
\text { cooperation with SMIDEC and } \\
\text { SME Bank. }\end{array}$ \\
\hline Univ Sains Malaysia & Credit bureaucracy & Bridging arrangement \\
\hline Univ Malaya & Staff and student lack of commitment & Awareness programs \\
\hline Univ Kebangsaan Malaysia & Leadership, communication & More time, expert. \\
\hline Univ Putra Malaysia & Mentality & Motivation \\
\hline Univ Teknologi MARA & Funding & $\begin{array}{l}\text { Dedicated fund, continuous } \\
\text { business opportunity }\end{array}$ \\
\hline Univ Malaysia Perlis & $\mathrm{X}$ & $\mathrm{X}$ \\
\hline Univ Utara Malaysia & $\begin{array}{l}\text { Funding, lack of information, networking, } \\
\text { Mentality, coordination among agencies }\end{array}$ & $\begin{array}{l}\text { Integrated program, agency } \\
\text { proactive, networking creation, } \\
\text { support }\end{array}$ \\
\hline Univ Malaysia Pahang & Coordination, no special unit, continuity & Continous support \\
\hline Univ Sultan Zainal Abidin & $\begin{array}{l}\text { No expertise. Bureaucracy, no support } \\
\text { from higher authority }\end{array}$ & $\begin{array}{l}\text { TOT, establishment of special } \\
\text { unit }\end{array}$ \\
\hline Univ Malaysia Terengganu & No special unit & Coordination \\
\hline Univ Perguruan Sultan Idris & Pedagogy & $\begin{array}{l}\text { More time, entrepreneurship } \\
\text { related subject }\end{array}$ \\
\hline Univ Pertahanan Malaysia & $\mathrm{X}$ & $\mathrm{X}$ \\
\hline Univ Sains Islam Malaysia & Culture nurturing & $\mathrm{X}$ \\
\hline Univ Teknikal Melaka & $\mathrm{X}$ & $\mathrm{X}$ \\
\hline
\end{tabular}




\begin{tabular}{lll}
\hline Univ Malaysia Sabah & $\begin{array}{l}\text { Lack of confidence, funding, experience, } \\
\text { marketing strategy }\end{array}$ & $\begin{array}{l}\text { Curriculum revamp, continuous } \\
\text { guidance from entrepreneurs }\end{array}$ \\
Univ Malaysia Sarawak & Funding, lack of experience & $\begin{array}{l}\text { Friendly } \\
\text { enhancement of training and } \\
\text { practice } \\
\text { Univ Islam Antarabangsa }\end{array}$ \\
X
\end{tabular}

Note: $\mathrm{X}$-None.

\section{Discussions}

The majority of Malaysia's public IHLs provide support for entrepreneurship education. The most common and popular form of support is the provision of business premises to allow students to run entrepreneurship activities. However, IHL managements do not cover some of the most critical in-business field activities for unknown reasons. The findings of this study show that a substantial number of IHLs face difficulties securing seed funding for student enterprises. In spite of this difficulty, some IHLs do offer seed capital in the form of soft loans, but the size of the funds is small. The amount allocated for seed capital by the university is small and managed by way of a revolving fund. Because they are revolving funds, their availiability depends on the repayment collected from the current borrower. The funds have constantly experienced a shortage since repayment is slow and erratic, and, as a result, the newly set up enterprise fails to secure the loan. In the worst case scenario, some IHLs experience high non-performing loans and have to stop the loan facilities. This is a common scenario happening when discussing entrepreneurship education in most IHLs. The findings of the study implicitly indicate that some IHLs are not serious in running and providing the necessary entrepreneurship support programs. Entrepreneurship is not all about selling products; the scope is wider to cover all business skills, including the individuals' hard and soft skills. Furthermore, many public IHLs do not have clear guidelines or policies related to their entrepreneurship education and activities. In the absence of student entrepreneurship policies and effective advisory services, the entrepreneurship programs will not be effective in achieving the intended goals. It is imperative for public IHLs to have clear policies as students may engage in business activities that have legal implications on them and on the university. Policies need to provide guidelines on actions that should be taken in the event that students encounter legal problems, so that such encounters will not negatively affect their studies.

Another significant finding from this study is about the trainers' skills. Some IHLs have simply been appointing trainers without considering their educational backgrounds and experiences. The results of this study indicate that some of the trainers have no qualifications to conduct entrepreneurship programs due to irrelevant education background and experience. This is a fundamental and crucial issue to ensure the success of these university's entrepreneurship programs. This phenomenon indicates that some IHLs' management do not see entrepreneurship education as a significant focal point. The management should be aware that entrepreneurship education is not only about learning the theories of business, but also it demands extensive exposure to personal practical experience, an effective pedagogical method, and an experienced and competent trainer.

The study's findings also indicate that the public IHLs have a mixed understanding of the objectives of entrepreneurship education. The majority of IHLs believe that that entrepreneurship education is to inculcate entrepreneurial characteristics to add value to graduates and to enhance the graduates' chance to attain employment. On the other hand, some IHLs' objective of entrepreneurship education is to produce entrepreneurs among their graduates. Different objectives require different pedagogy for the programs to be successful. Mixed understandings of the objective affects the uniformity in the implementation of the programs. The time has come for the highest authority, i.e. MOE, to introduce a new entrepreneurship education model that is more effective and that integrates both objectives.

Regarding the examination of the pedagogy applied by the public IHLs, the findings of this study show that the entrepreneurship education delivery system is less effective. Most of the teaching approaches are generic and fail to inculcate entrepreneurship's true value. The findings also indicate that lectures are the most common and popular methodology in the delivery of entrepreneurship education, over methods such as business simulation, role play, and case studies. Teaching methods that are teacher-centred may be appropriate in the context of explaining theoretical concepts; however, such a method is not able to provide actual experience and consequently the knowledge fails to be put into practice and students' learning experience is not maximized.

In terms of the impact of the programs, the findings indicate that there has not been a significant impact on 
graduates' tendency to choose entrepreneurship as a career. IHLs have invested a considerable sum of money in providing the resources needed for the implementation of entrepreneurship education programs and activities; however, the percentage of graduates who want to take up entrepreneurship as a career option is very low and far from achieving the target. The failure to promote entrepreneurship as a career among graduates seems to be caused by the lack of an effective entrepreneurship education model with realistic goals. Currently, most of the entrepreneurship education programs do not have specific learning outcomes and have been implemented in silos. In other words, the programs have failed to support the two prong objectives of entrepreneurship education in Malaysian public IHLs.

To summarize, the methodology used in entrepreneurship education should focus on the entrepreneur's attitudes and attribute development, which were earlier identified, such as internal locus of control, optimism, commitment and confidence, problem solving skills, and risk-taking propensity, among others. Current methods that adopt traditional teaching, such as through a theoretical framework and being examination-oriented, are less practical in efforts to attract students to venture into business after graduation. The problem is compounded when the entrepreneurial class is conducted by instructors or lecturers who are not qualified and never have been exposed to entrepreneurship training. Such a situation is awkward for someone to have to talk about entrepreneurship without having a formal education background and never having taken training or courses to enhance his or her entrepreneurial knowledge. Thus, to ensure the effectiveness of the entrepreneurship education programs, a new method of entrepreneurial teaching and learning and revision of the current curriculum should be undertaken in order to boost the understanding of the entrepreneurial process and the way to nurture an entrepreneurial attitude. The entrepreneurship curriculum needs to include courses that are geared towards the development of students' business acumens and entrepreneurial motivation. Business acumens cover financial literacy and general management, human resources management, communications, legal, and marketing skills. Entrepreneurial skills refers to the ability to assess risk and creativity and the ability to identify business opportunities. Based on the Babson College's practices, experience-based learning can improve skills and motivate students to venture into entrepreneurship. Past studies have shown that learning based on experience is more effective than the traditional way of learning. The time has come for a comprehensive model of entrepreneurship education to be formulated and implemented in order to enhance the effectiveness of entrepreneurial teaching and learning. The success of the entrepreneurship education would be the beginning of a new era of entrepreneurship as a career of choice.

\section{Recommendation}

Based on the above findings and discussion, this study suggests the stakeholder to introduce a new entrepreneurship education model that integrates entrepreneurship education and enterprise education. This study proposed the new model which is called Entrepreneurship Education and Enterprise Education Model or in brief the $4 \mathrm{e}$ Model. The graphical model is shown in Figure 1.

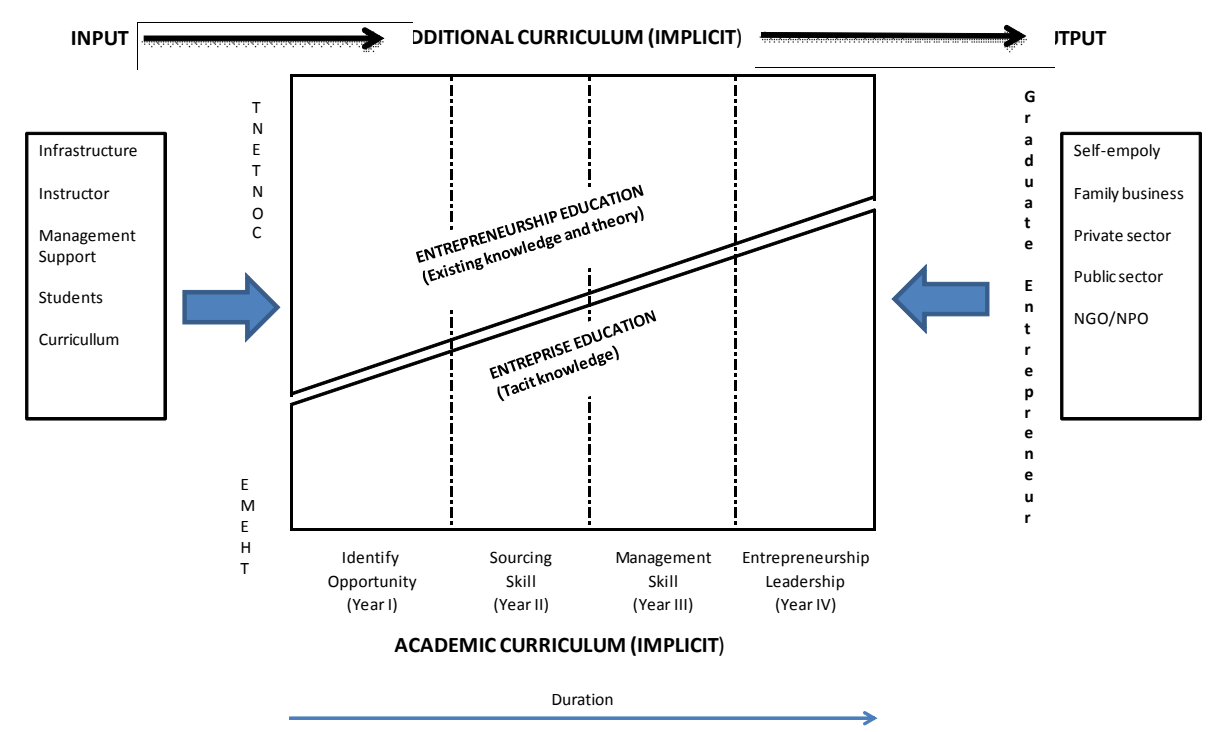

Figure 1. Education and enterprise education model (The 4e Model) 
The proposed model adopts the input-transformation-output process of entrepreneurial learning. The transformation process where the learning experience is maximized consists of two major components, i.e. the entrepreneurship education and the enterprise education. Entrepreneurship education refers to a curriculum designed to embed the knowledge based education and theoretical context of entrepreneurship (established knowledge and theories) in the artificial environment (classroom context). Students are exposed to entrepreneurship knowledge, such as entrepreneurial behaviour, entrepreneur mind set, attributes and entrepreneur characteristics, preparation of business plans, management of small businesses, entrepreneurship process among others. For this component, the teaching pedagogy suggested include lectures, workshops, simulations, case studies, role play and guest speakers to name a few.

The second component, i.e. Enterprise education refers to a curriculum that emphasizes on fostering and enhances students' tacit knowledge (learning for entrepreneurship in real environment or setting). The curriculum provides an opportunity for students to actually execute their proposed projects proposed and learn through observation, experience and/or discovery. This educational approach grants an opportunity for students to learn and make decisions. Students are exposed to take responsibility and risk assessment on every action taken. Implicitly, learning by experience would boost their confidence level and practice the prudent concept in their work despite of the outcome of their decision (failure or success). New knowledge gained from this process which known as tacit knowledge is very valuable and would be useful in future.

Table 5. The difference between entrepreneurship education and enterprise education

\begin{tabular}{ll}
\hline Entrepreneurship Education & Enterprise Education \\
\hline $\begin{array}{l}\text { Emphasise on the delivery of existing } \\
\text { entrepreneurship theories and knowledge }\end{array}$ & $\begin{array}{l}\text { Emphasise on the cultivation of tacit knowledge } \\
\text { through actual experience and business practices } \\
\text { in self-selected project }\end{array}$ \\
$\begin{array}{l}\text { Artificial setting or environment } \\
\text { Knowledge is learned }\end{array}$ & $\begin{array}{l}\text { Real setting or environment } \\
\text { Knstructors may non-practitioners }\end{array}$ \\
$\begin{array}{l}\text { Learning through observation, experience and } \\
\text { discovery, guided by practitioners }\end{array}$ \\
$\begin{array}{l}\text { Only able to create interest and understanding create entrepreneurs among graduates } \\
\text { Hardly to measure the student's competency level } \\
\text { as its subjective nature }\end{array}$ & $\begin{array}{l}\text { The level of competency can be objectively } \\
\text { measured } \\
\begin{array}{l}\text { Pedagogy-lectures and tutorial, case study, } \\
\text { simulation, role play and invited speakers. }\end{array} \\
\text { Pedagogy-enterprise learning, entrepreneurship } \\
\text { week, field work, student mall and business } \\
\text { incubator. }\end{array}$ \\
\hline
\end{tabular}

\subsection{The Rationale for the Proposed 4e Model}

The $4 \mathrm{e}$ Model is the combination of theoretical and experiential learning. The traditional entrepreneurship education alone is less effective to develop entrepreneurial competencies. The traditional way of teaching only fit when the audience is attracted on the knowledge, but do not have the opportunity to put into practice. No doubt entrepreneurship education is important, however, without enterprise education which focus on learning through experience, the objective to develop enterprising graduates is amidst.

The 4e Model clearly categorises the contents based on level of study for both entrepreneurship and enterprise education. In general, the level of study is divided into four phases. At the beginning level, the curriculum is focusing more on entrepreneurship education and decreasing along the period of study. Subsequently, towards the end of the study, students are exposed more to enterprise education to allow for implementation of the business plan which was prepared in the earlier level.

The success of the $4 \mathrm{e}$ Model very much depends on the quality of input and methodology applied in the teaching and learning process. The inputs among others include infrastructure, lecturer/instructor, administrative support, curriculum and students. The $4 \mathrm{e}$ Model applies outcome based learning approach where the learning outcomes and entrepreneurial competencies can be measured objectively. The objective measurement made is based on evidence-based learning as compared to psychometric test which is too subjective. The 4e Model requires students 
to keep evidence into a personal folio, then evaluated by the academic advisor at the end of the semester. For students, the folio is a conclusive evidence for involvement in entrepreneurial activities during their study and would be very helpful during job interviews. By using the outcome based learning, the assessment of the goal achievement is far more credible and reliable.

The $4 \mathrm{e}$ Model outlined the characteristic of the entrepreneurial graduates. The dispositional characteristics among others, are leadership, creative, innovative, dare to take calculated risks, persuasive, opportunity driven, integrity and with excellent communication skills. The model would also help to develop self- confidence among students by nurturing internal locus of control and positive affectivity. Preparing graduates with these attributes would enhance their entrepreneurial ability and competency. The $4 \mathrm{e}$ Model does not propagate creating a new venture is a must for graduates, but offer options and alternative routes for them to make a choice. Graduates may decide later whether to be self-employed, engage in the family business, or work with private or public sector or with non-governmental organisations (NGOs). Regardless of their choice of career, the most important is that graduates are able to apply and implement their entrepreneurial knowledge and skills in their new working environment thus benefiting the organization and society.

\section{Conclusion}

This paper provides an overview of the implementation of entrepreneurship education in all local IHLs. The information gathered is of paramount importance in reviewing the existing education model that leads to the proposal of new comprehensive entrepreneurship education model to be implemented by Malaysia's IHLs. The success of the proposed $4 \mathrm{e}$ Model depends crucially on the commitment and seriousness of the stakeholders involved. It should be noted that among the critical success factors for the $4 \mathrm{e}$ Model are (1) a conducive entrepreneurship ecosystem in IHLs, (2) strong support from the IHLs' management and stakeholders, (3) a clear policy on the entrepreneurial activities in IHLs, (4) commitment from members of faculty, departments, and units, and (5) an entrepreneur-friendly support system. Finally, the 4e Model is set to act as a guideline to inculcate entrepreneurial characteristics among graduates. These are the graduates who are opportunity seekers and job creators. As a conclusion, the successful implementation of the proposed model would lead to public IHLs being recognised as the best place to generate entrepreneurial human capital for the country.

\section{References}

Cheng, M. Y., Chan, W. S., \& Mahmood, A. (2009). The effectiveness of entrepreneurship education in Malaysia. Education + Training, 1(7), 555-566. http://dx.doi.org/10.1108/00400910910992754

Dahlan, I., Hakimin, Y., \& Azwin, N. (Eds.). (2010). The relationship between tacit knowledge and entrepreneurial orientation among university students (Vol. 1). Kelantan: Universiti Malaysia Kelantan.

Dhliwayo, S. (2008). Experiential learning in entrepreneurship education. A prospective model for South Africal tertiary institutions. Education + Training, 50(4), 329-340.

Drucker, F. P. (1994). Innovation and entrepreneurship. Butterworth-Heinemann, Oxford.

Fayolle, A., \& Gailly, B. (2008). From craft to science: Teaching models and learning processes in entrepreneurship education. Journal of European Industrial Training, 32(7), 569-593. http://dx.doi.org/10.1108/03090590810899838

Gorman, G., Hanlon, D., \& King, W. (1997). Some research perspective on entrepreneurship education, enterprise education and education for small business management: A ten year literature review. International Small Business Journal, 15(3), 56-77. http://dx.doi.org/10.1177/0266242697153004

Jones, C., \& English, J. (2004). A contemporary approach to entrepreneurship education. Education + Training, 46(8/9), 416-423. http://dx.doi.org/10.1108/00400910410569533

National SME Development Council. (2007). SME Annual Report 2007. Kuala Lumpur.

Nurmi, P., \& Paasio, K. (2007). Entrepreneurship in Finnish universities. Education + Training, 49(1), 56-66. http://dx.doi.org/10.1108/00400910710729884

Pretorius, M., Nieman, G., \& van Vuuren, J. (2005). Critical evaluation of two models for entrepreneurial education: An improved model through integration. International Journal of Educational Management, 19(5), 413-427. http://dx.doi.org/10.1108/09513540510607743

Tan, S. S., \& Ng, F. C. K. (2006). A problem-based learning approach to entrepreneurship education. Education + Training, 48(6), 416-428. http://dx.doi.org/10.1108/00400910610692606

Van Vuuren, J., \& Nieman, G. (1999). Entrepreneurship education and training: A model for syllabi/curriculum 
development. Paper presented at the 44th ICSB World Conference Proceedings.

\section{Copyrights}

Copyright for this article is retained by the author(s), with first publication rights granted to the journal.

This is an open-access article distributed under the terms and conditions of the Creative Commons Attribution license (http://creativecommons.org/licenses/by/3.0/). 